\title{
Finnish Mentor Mathematics Teachers' Views of the Teacher Knowledge Required For Teaching Mathematics
}

\author{
Mervi A. Asikainen ${ }^{1}$, Erkki Pehkonen ${ }^{2} \&$ Pekka E. Hirvonen ${ }^{1}$ \\ ${ }^{1}$ Department of Physics and Mathematics, University of Eastern Finland, Joensuu, Finland \\ ${ }^{2}$ Department of Applied Sciences of Education, University of Helsinki, Helsinki, Finland \\ Correspondence: Mervi Asikainen, Department of Physics and Mathematics, University of Eastern Finland, P.O. \\ Box 111, FI-80101 Joensuu, Finland. E-mail: mervi.asikainen@uef.fi
}

\author{
Received: November 2, 2012 Accepted: December 5, 2012 Online Published: January 25, 2013 \\ doi:10.5539/hes.v3n1p79 \\ URL: http://dx.doi.org/10.5539/hes.v3n1p79
}

\begin{abstract}
Seven Finnish mentor mathematics teachers were interviewed about their views regarding the teacher knowledge required for teaching mathematics. The results of the interviews revealed not only the teachers' spontaneous views of the knowledge base needed for effective mathematics teaching but also their views of the particular types of teacher knowledge required for teaching mathematics that have been emphasized in the research literature. When the teachers freely described their views, issues related to content knowledge and the requisite knowledge for teaching mathematics were emphasized. The teachers valued most of the knowledge types available, even if only a few of them had highlighted them earlier in the interview. Some types, however, remained ambiguous from the teachers' perspective. Our findings suggest that even if the mentor teachers are considered experts in mathematics teaching, they are not necessarily able to conceptualize their view of the knowledge required for mathematics teaching, or they may have their own views of the necessary types of knowledge. This in turn may impede student teachers in connecting their educational studies with mathematics studies during student teaching. In addition, it was found that mentor teachers frequently hold personal views about the importance of the types of mathematics teacher knowledge that may be valuable for student teachers when they are reflecting their own view of the requisite knowledge for teaching and the type of a teacher they want to become.
\end{abstract}

Keywords: knowledge for teaching, mathematical knowledge for teaching, mentor teachers' views, teacher knowledge

\section{Introduction}

The Finnish mathematics teacher's education programs include three years of Bachelor's studies (180 credits) and two years of Master's studies (120 credits), taken full time. These two levels together give a competence to teach at both lower and upper secondary school levels These studies consist of courses in mathematics (130 credits) and also in one or two minor subjects (60 credits each), typically physics or chemistry, or both of them. In addition, pedagogical studies (60 credits) organized by the various Faculties of Education are one requisite part of teacher education programs. These one-year studies deal with both general theories of learning and teaching and also the special features of mathematics learning and teaching.

One very important part of subject teacher studies is student teaching at a university practice school, which occupies about 20 credits of the pedagogical studies. The national curriculum is followed in these schools; thus they can be considered authentic school environments for student teaching. The subject teachers, who are working at a university practice school, mentor teachers, guide student teaching alongside their own conventional teaching work. The mentor teachers hold at least a Master's degree. The qualification required to apply for a post of a mentor teacher consists of minimum of two years' teaching experience at secondary level and a practical demonstration of skilful teaching. (See Asikainen \& Hirvonen, 2010)

The mentor teachers who tutor the student teaching play an important role in student teaching in general and can have an influence on the types of teachers that their student teachers will become (e.g., Rhoads, Radu \& Weber, 2011). According to published studies, mentor teachers give student teachers individual support and help them to develop their professional skills (Anderson, 2006). Good cooperating teachers have time for their student 
teachers; they encourage and motivate them, and share their ideas and knowledge about effective teaching (Koerner, O'Connell Rust, \& Baumgardner, 2002). Student teachers also value a friendly and supportive relationship with cooperating teachers and appreciate cooperating teachers who gave them a freedom to use their own teaching methods (Rhoads, Radu, \& Weber, 2011). On the other hand, as teacher educators, mentor teachers should be able to challenge student teachers' existing beliefs and practices (Pajares, 1992) and shape their pedagogical thinking and action (Borko \& Mayfield, 1995).

In the Finnish system the mentor teachers are not voluntary teachers in communal schools but teachers employed at the university practice school, and as such are regarded as "experts in teaching". As teacher educators responsible for student teaching they should be able to discuss both the practical and the theoretical aspects of teacher's profession with the student teachers. Different aspects of teacher knowledge in mathematics are undoubtedly a theoretical and pedagogical issue with which every mentor teacher should be familiar and be capable of fluently exchanging her/his personal views of the field with the student teachers.

\section{Background and Research Questions}

\subsection{Teacher Knowledge Required for Teaching Mathematics}

It has been argued that the quality of a teacher's own knowledge has a strong influence on how that knowledge is linked and used during the preparation of lessons and in their teaching (Lawson \& Chinnappan, 1994; Schonfeld, 1992). This suggests that mentor teachers' knowledge is very important in modeling quality teaching and helping student teachers in their professional development.

Teachers' knowledge has been classified to understand what kind of knowledge base makes a skilful teacher. Term subject matter knowledge refers to the extent and organization of a teacher's subject matter knowledge (e.g., Shulman, 1999). It can be considered to be a premise for understanding a discipline (Boz \& Boz, 2008). In mathematics, concept mathematical knowledge can be regarded as the structure of mathematical objects, for instance, rules, concepts, theorems, or theories that are interrelated and connected with components of the external world (Chinnappan \& Lawson, 2005; Brinkmann, 2001; Chapman, 2004). (Note 1) There is no doubt that an understanding of the structure of mathematical knowledge and of the theory of mathematics is a cornerstone of mathematics teachers' knowledge base. Furthermore, knowledge of the history of mathematics could possibly also provide an approach to introducing new topics to students and act as a huge source of information related to numerous problems (e.g., Fauvel \& van Maanen, 2000).

Subject matter knowledge is not sufficient for effective teaching, but a teacher should also have general pedagogical knowledge. General pedagogical knowledge is essential for all teachers because it includes knowledge of general variables of instruction, like classroom management, pacing, and questioning strategies (Boz \& Boz, 2008).

When a teacher's content knowledge and pedagogical knowledge combine, pedagogical content knowledge (PCK) develops. For instance, a teacher's understanding of how certain topics, problems, or issues are organized, represented, and tailored to the various interest and abilities of learners are types of PCK (Shulman, 1987, p. 8).

Research has shown that effective mathematics teachers have a rich and flexible knowledge of both mathematics and pedagogy; if the teacher is able to integrate mathematics and pedagogy and apply the composite result in a particular learning context, excellent teaching can take place (Steele, 2005). For instance, to develop an understanding of mathematics for teaching, one has to be able to think pedagogically about mathematics (Feiman-Nemser \& Buchmann, 1986). Ball (1988) refers to this knowledge as subject matter knowledge for teaching, a form of mathematical knowledge that teachers use when they teach mathematics (see also Stylianides \& Ball, 2008). Hill, Blunk, Charalambous, Lewis, Phelps, Sleep, and Ball (2008) use the term "mathematical knowledge for teaching" that consists of both mathematical knowledge that all professionals in the field of mathematics possess and mathematical knowledge typical for mathematics teachers.

A mathematics teacher should know different instructional approaches for teaching mathematics. Instructional approaches are action schemes that guide processes of teaching and learning (Kurki-Suonio \& Kurki-Suonio, 1994). When a teacher follows a particular approach to teaching, "the strategies used and the contents chosen for the teaching form a coherent ensemble that takes into account several factors, for example the level of the students' understanding, the instructional aims, and the contents of the teaching" (Asikainen \& Hirvonen, 2010). For instance, a conceptual change approach (Vosniadou \& Verschaffel, 2004), a knowledge-centered approach (Lerman, 1983), and problem-solving (see Schoenfeld, 1992), are examples of different types of instructional approaches that can be used in the teaching of mathematics to develop students' mathematical thinking.

Knowledge of students' preconceptions is also an essential part of mathematics teaching. In order to promote 
students' learning, a teacher has to know the common conceptions and misconceptions as well as the reasoning models that students have and use (Cobb, Yackel, \& Wood, 1992; Cobb \& Steffe, 2011). This type of knowledge can be shaped from the research literature related to students' conceptions and understanding. In addition, knowledge of students' attitudes is important for any teacher because research has shown that such attitudes can be related to students' achievement in mathematics (Zan, Brown, Evans \& Hannula, 2006; Ma \& Xu, 2004).

Software tools and computer-aided learning materials are becoming increasingly popular in modern mathematics teaching. Therefore, knowledge of computer-based tools and resources is vital for a mathematics teacher. For instance, computer-based tools can be used as providers of fast feedback for students, as tools for visual displays of mathematical figures, as tools for pupils to manipulate mathematical figures, or as aids in making calculations that cannot be done quickly manually (e.g., Reynolds, Treharne, \& Tripp, 2003; Haapasalo \& Silfverberg, 2007). Computers are therefore strongly related to visualizations. Nowadays visualization in mathematics education is not limited to illustrations but is recognized as a key component of reasoning, problem-solving or even proving (Arcavi, 2003). Concretization and hands-on mathematics by using manipulatives can provide learners with opportunities to develop their own representations and thus to build their knowledge structures if they are used in an appropriate manner in teaching (Clement, 1999).

\subsection{Aims of This Study}

In the present study we focus on mentor mathematics teachers' views of teacher knowledge in mathematics. These have thus far been rather neglected in the research literature. We are interested in the kind of views that Finnish mentor mathematics teachers working at university practice schools hold about teacher knowledge in mathematics and also in how these views are related to the views represented in the research literature. In consequence, this study seeks answers to the following research questions:

1. What kind of views do Finnish mentor mathematics teachers possess about the knowledge base of a skilful mathematics teacher?

2. What kind of views do Finnish mentor mathematics teachers possess about the types of teacher knowledge required for teaching mathematics as presented in the literature?

It is interesting to find out the most important types of knowledge in mentor teachers' thinking. From this kind of information, we may be able to better understand the premises that mentor teachers use for nurturing student teachers' professional development during their student teaching. One of the ways in which this information can be obtained is by questioning the various types of mathematical knowledge for teaching mathematics as interview themes information on the relative extent of their familiarity with the subjects. Previous research indicates that student teachers may have difficulties in seeing the connection between mentor teachers' teaching and educational theories (Black \& Halliwell, 2000; Meijer, Verloop, \& Beijaard, 1999). Hence, the results may reveal the possible reasons for such difficulties and also reveal gaps in mentor teachers' knowledge, which in turn may indicate a need for extra training for mentor teachers themselves.

\section{Method}

\subsection{Sample}

Our subject group consists of mentor mathematics teachers from two university practice schools in Finland. The teachers were asked to participate in a study based on the recommendations of mathematics teacher educators at the two universities. Altogether, seven of the eight teachers who were approached volunteered for the study. In Finland there are only seven universities providing mathematics subject teacher education and eight teacher training schools with mentor mathematics subject teachers. Generally speaking, five or six mathematics majors are working at one teacher training school, so our sample encompasses about $15 \%$ of all Finnish mentor mathematics subject teachers.

The sample of mentor teachers taught both levels at secondary school. The teaching experience of the selected teachers varied between 8 and 36 years and the guiding experience between 1 and 29 years (see Table 1). Four of the teachers were female and three male.

Table 1. Teaching and mentoring experience of the interviewed mentor mathematics teachers (the names used are pseudonyms)

\begin{tabular}{lccccccc}
\hline & Rita & Laura & Jenny & Mike & David & Eric & Julie \\
\hline Teaching experience (years) & 21 & 14 & 28 & 8 & 4.5 & 29 & 36 \\
Mentoring experience (years) & 17 & 9 & 3 & 1 & 4.5 & 8 & 29 \\
\hline
\end{tabular}




\subsection{Instruments}

This pragmatic study was implemented with semi-structured interviews (Wengraf, 2001). A semi-structured interview was selected as a research instrument because the mentor teachers most commonly interact with student teachers via speech. Therefore, an interview is a natural way to study their views of teacher knowledge. The mentor teachers are also very busy and the interview method took only little of their time.

The interviews took 30-60 minutes, and they were conducted at the mentor teachers' schools in 2007. The interview consisted of two successive parts that were tested before the actual data collection by interviewing a voluntary mathematics teacher in order to ensure that the interview would measure the desired aspects. The first part of the interview was designed to discover subjects' views about the knowledge base of a skilful mathematics teacher. Because we were interested in hearing the subjects' personal views, we used open-ended questions and tried to avoid prompting. In addition, the subjects were asked to describe their views freely. (Note 2)

The second part of the interview was designed to discover mentor teachers' views in more detail, and it dealt with the types of mathematical knowledge required for teaching mathematics, as introduced in the theoretical contextualization of this article (see Figure 1). (Note 3) The mentor teachers were asked to take a stand on the types and to validate their views.

\begin{tabular}{|l|}
\hline Structure of mathematical knowledge \\
Theory of mathematics \\
Student's preconceptions and attitudes \\
Instructional approaches \\
Computer-based tools and resources \\
History of mathematics \\
Mathematical problem-solving \\
Visualizations and hands-on work \\
\hline
\end{tabular}

Figure 1. The types of mathematical knowledge for teaching mathematics used as interview themes

\subsection{Analysis of the Data}

The analysis was mainly qualitative, but quantitative methods were also used to improve the credibility of the study (Johnson, Onwuegbuzie, \& Turner, 2007). For the analysis, the interviews were transcribed. In the first part of the study, where the aim was to discover what kind of views mentor teachers held concerning the teacher knowledge of a skilful mathematics teacher, the analysis included several cycles of reading of the mentor teacher's responses where the data was compressed, arranged, and categorized to establish, firstly, the subcategories and then also the main categories (Huberman \& Miles, 1994). The analysis was content-driven because the researcher (M. A.) was already aware of the literature in the field of mathematics teacher education.

In the second part of the study, where the aim was to discover how mentor teachers regarded the importance of the types of mathematical knowledge required for teaching mathematics, the analysis was slightly different. In this part, the responses were compressed and sorted, and the participant's views of the different domains were categorized (Huberman \& Miles, 1994).

In order to ensure the credibility of the study, the third author (P. H.) double-checked the categorization, and the researchers discussed the divergent interpretations to identify a consensus view (Kvale, 1996). A consensus between the researchers about the categorization of the data was reached after discussion of the two differences in 25 interpretations (Cohen's kappa $\kappa=0.92$ ) in part one and one difference in 56 interpretations (Cohen's kappa $\kappa=0.98)$ in part two.

In order to allow the reader to assess the analysis process and conclusions of the researchers, quotations from participants' interview responses are presented here.

\section{Results}

The results are presented in two sections. Firstly, the results related to mathematics teachers' spontaneous views about the knowledge base of a skilful mathematics teacher are described. Secondly, the results of their views of the types of mathematical knowledge required for teaching mathematics are presented. 


\subsection{Mathematics Teachers' Views of the Knowledge Base of a Skilful Mathematics Teacher}

When the teachers were asked to describe the knowledge base of mathematics teachers, all of the teachers started with subject matter knowledge. They emphasized the importance of subject matter knowledge as a foundation of mathematics teachers' knowledge.

Three mathematics teachers understood subject matter knowledge to consist of a profound mastering of the subject matter knowledge and four teachers thought that teacher's subject matter knowledge meant an understanding of the structure of mathematics (see Table 2). David explained his thinking by saying that "a teacher has to see how the domains and concepts of mathematics are interrelated". Both Eric and Julie added that a teacher has to possess knowledge of the nature of mathematics as a science as well.

After the teachers had expressed their ideas about subject matter knowledge, they usually turned to the mathematics teacher's knowledge that they each used in teaching mathematics. The teachers' unique and personal views about the teachers' knowledge required for teaching are presented in Table 2.

Table 2. Mathematics teachers' views of knowledge of a mathematics teacher

\begin{tabular}{|c|c|c|c|c|c|c|c|}
\hline Presented knowledge dimensions & Rita & Laura & Jenny & Mike & David & Eric & Julie \\
\hline \multicolumn{8}{|l|}{ Subject matter knowledge } \\
\hline Mastering of subject matter knowledge & $\mathrm{X}$ & $\mathrm{X}$ & $\mathrm{X}$ & & & & \\
\hline $\begin{array}{l}\text { Mastering of subject matter knowledge means } \\
\text { knowledge of structures of mathematics }\end{array}$ & & & & $\mathrm{X}$ & $\mathrm{X}$ & & \\
\hline $\begin{array}{l}\text { Mastering of subject matter knowledge includes } \\
\text { knowledge of the structure of mathematics and } \\
\text { knowledge of the nature of mathematics as a } \\
\text { science }\end{array}$ & & & & & & $\mathrm{X}$ & $\mathrm{X}$ \\
\hline \multicolumn{8}{|l|}{ Pedagogical knowledge } \\
\hline Transformed subject matter knowledge & $\mathrm{X}$ & & $\mathrm{X}$ & $\mathrm{X}$ & & $\mathrm{X}$ & \\
\hline Structures of mathematics in teaching & & & & & $\mathrm{X}$ & $\mathrm{X}$ & \\
\hline How to teach mathematical knowledge & & & $\mathrm{X}$ & & & & $\mathrm{X}$ \\
\hline How to teach logical thinking and reasoning & & & $\mathrm{X}$ & & & & \\
\hline Mathematical problem-solving & & & $\mathrm{X}$ & & & & \\
\hline How to teach students to work precisely & & & $\mathrm{X}$ & & & & \\
\hline Student-centered activities & & & & & $\mathrm{X}$ & & \\
\hline Students as mathematics learners & $\mathrm{X}$ & & $\mathrm{X}$ & $\mathrm{X}$ & & $\mathrm{X}$ & \\
\hline \multicolumn{8}{|l|}{ General pedagogical knowledge } \\
\hline Learning theories & & & & & & & $\mathrm{X}$ \\
\hline Guiding and evaluation of student learning & & $\mathrm{X}$ & & & & & \\
\hline
\end{tabular}

As Table 2 indicates, four teachers, Rita, Jenny, Mike and Eric, stated that, for the purposes of teaching, a mathematics teacher has to have a capacity for transforming subject matter knowledge. These same four teachers considered knowledge of students to be important for a mathematics teacher. On one hand, Rita said:

"If you know mathematics, it does not mean that you are able to transfer it to somebody else. You have to transform it into a form that is understandable even for those students who have learning problems." [Rita]

On the other hand, Jenny's quote shows how a knowledge of students and transformed subject matter knowledge are interconnected in these teachers' responses:

"A teacher has to be able to pass on his/her knowledge base to students so that teaching takes place at the students' level of development. This is not necessarily easy because teaching groups can differ." [Jenny]

Two teachers, Eric and David, emphasized knowledge of the structures of mathematics in mathematics teaching. Their standpoints were, however, slightly different. On one hand, for Eric structures in mathematics teaching 
meant that the teacher needed to see how different dimensions are treated in teaching at different school levels and to be able to create a continuum from lower secondary school level to high school level. He stated that he also explicitly impresses the importance of lower secondary school level mathematics studies on his students. David, on the other hand, stated that mathematics teaching should be logical, regardless of the teaching methods used. By this means, the typical interconnections and structures of mathematics can be demonstrated to students. In addition, David stated that a mathematics teacher should know the structures of mathematics well enough to differentiate the most essential issues in the content so as to be able to concentrate on them in teaching.

Two of the teachers, Julie and Jenny, spoke about the teachers' knowledge involved in the teaching mathematical knowledge. Julie used the term "didactics of mathematics". By this she meant knowledge of mathematics teaching: mathematics has special features and it cannot be taught in the same way as, for example, English or history. German Didactics is a wide theory covering the design and implementation of teaching that was commonly used in northern and central Europe until the 1980s (e.g., Klafki, 2000; Hopmann \& Riquarts, 2000; see also Asikainen \& Hirvonen, 2010).

The rest of the knowledge dimensions shown in Table 2 received only single references. Laura considered that a mathematics teacher should be able to guide students' learning processes and evaluate learning. David considered that knowledge of student-centered classroom activities was important for a mathematics teacher. He said: "A skilful mathematics teacher motivates students to think, discover and figure out different regularities, calculations and strategies as much as possible by themselves."

According to Jenny, it is not enough that students master mathematics technically in order to understand it:

"Mathematics teaching should develop students in many kinds of ways. For example, it can help students to improve logical thinking and reasoning skills and to learn mathematical problem-solving and accurate working methods." [Jenny]

A mathematics teacher has to have knowledge of mathematics him/herself in order to have a proper capacity for teaching the skills. Julie also stated that a mathematics teacher has to have knowledge of the theories of learning.

In sum, the teachers generally agreed on the importance of subject matter knowledge. The most often mentioned knowledge types for teaching were transformed subject matter knowledge and knowledge of students as mathematics learners. Most of the types were mentioned only once or twice. It should also be noted that knowledge for teaching mathematics can be identified as pedagogical content knowledge (PCK) in mathematics, a knowledge that a teacher uses to transfer subject matter knowledge for teaching purposes (see Shulman, 1987). The teachers did not, however, use the term PCK.

\subsection{Mathematics Teachers' Views of the Mathematical Knowledge Required for Teaching Mathematics}

The second part of the interview dealt with mentor teachers' conceptions of the types of mathematical knowledge required for teaching mathematics; these are listed in Figure 1. The mentor teachers agreed unanimously about the importance of six of the eight types of knowledge, whereas two of the types, computer-based tools and resources and the history of mathematics, polarized their views. In the following, the issues will be discussed in detail.

\subsubsection{Understanding the Structure of Mathematical Knowledge and Mathematical Theory}

All the mentor teachers emphasized the importance of understanding the structures of mathematical knowledge. Eric stated that the teaching of mathematics aims at developing students' understanding of the structure of mathematical knowledge. Jenny emphasized the importance of knowing what students already know: knowledge that is taught has to be tied to existing knowledge structures in mathematics teaching. David, for his part, saw two dimensions in knowledge of structure of mathematics:

"As a mathematician would say, on one hand, there are axioms, then come definitions, and finally, different theorems occur. This can be called the organized form of learned knowledge. On the other hand, in learning mathematics the route is different. First, an image of concept is constructed, then the concept is named, and so on." [David]

Most of the teachers regarded knowledge of the structure of mathematics and knowledge of the theory of mathematics as existing in parallel. For instance, Rita stated: "An understanding of the structure of mathematics and the theory of mathematics are quite parallel to each and are used as a basis for teaching." It was difficult for the teachers to distinguish between these two aspects, as Eric's statement shows: "The theory of mathematics forms an important part of mathematics learning because mathematics is based on axioms, theorems and theories." In fact, Eric is referring here to the structure of mathematical knowledge. Jenny considered that an 
understanding of the theory of mathematics is emphasized more at the upper secondary school than at lower secondary school.

\subsubsection{Students' Preconceptions and Attitudes}

Students' preconceptions and attitudes were also a valued dimension of mathematics teachers' knowledge. Laura stated that they played a very important role in the design of teaching and she considered them issues that should be taken into account in teaching. She had also noticed that student teachers were likely to pay a lot of attention to them - and perhaps even too much: "Some student teachers seize on students' preconceptions and attitudes and use over half of a lesson to identify them. I guess it's due to their pedagogic studies".

Julie stated that a teacher's knowledge of students meant that $\mathrm{s}$ /he would know what kind of conceptions and attitudes students have. She continued:

"It is easier to start teaching if you know what kind of conceptions students already have because you cannot know them based on the curriculum. The teacher should discover this [pre-knowledge] somehow. The topic is rarely completely new to students, and existing knowledge can be insufficient or inaccurate. For example, fractions are a topic that is very idiosyncratic in students' minds. Students' attitudes towards mathematics appear as early as in primary school and they are very difficult to change later on." [Julie]

Mike also shared Laura's view of the difficulty of changing students' preconceptions, especially at upper secondary level: "You can no longer change students' preconceptions at upper secondary school, or at least it tends to be very hard to do so."

Eric believed that a teacher had a strong influence on students' attitudes. He also thought that students' attitudes to and interest in mathematics are interrelated: "if a student's attitude to mathematics is negative, a teacher has to do a lot of work to motivate the student". According to Jenny, many people have a conception of themselves as mathematics learners, such as "I hated/loved mathematics" or "I can/can't understand mathematics", and these kinds of conceptions can already be found in very young pupils. In fact, Jenny is talking about self-efficacy (Bandura, 1977), even though she does not use the concept as such. She thought that elements such as mathematical problem-solving, funny or logical problems, the history of mathematics, and illustrations and experimental work can make mathematics more interesting to those students who are otherwise uninterested in mathematics in a "technical" sense.

\subsubsection{Instructional Approaches in Mathematics}

All the mentor teachers considered knowledge of instructional approaches essential for a mathematics teacher. Julie thought that a teacher's knowledge of instructional approaches has a connection with teachers' knowledge of students, how they can be motivated, and how different skills can be taught. The following quote shows that Julie certainly has a personal instructional approach of her own:

"It means that the teacher knows the students and what issues are difficult for them. The teacher also knows if there are some weak or talented students in the class. The teacher has to be able to start teaching interestingly in order to motivate students. One aim of teaching is also to teach students different skills." [Julie]

David also thought that teachers' knowledge of students' pre-knowledge and knowledge of teaching groups affects the selection of instructional approach. He suggested that the use of experimental work and illustrations were potential instructional approaches that are based on modern conceptions of learning.

Rita also emphasized a teacher's knowledge of students and teaching groups as a starting point of teaching. She explained:

"The teacher has to decide whether s/he uses prompting in order to guide students towards discovering the matter at hand, for instance, regularity. Prompting leads to the discovery of regularity, which can then be adopted [by the students]. Or the teacher can simply present a topic directly and that will be that!" [Rita]

On the basis of this quote it can be concluded that Rita's view of an instructional approach is rather narrow and in her mind approaches are methods rather than approaches in a broader sense. Jenny also had a conception that was similar to Rita's, because she stressed that it was important "how the teacher approaches the topic", especially at the lower secondary school.

Eric referred to instructional approaches as ways of presenting mathematics to students. He emphasized that approaches are constructed on the basis of different conceptions of learning:

"It is important to notice whether it is model-based or discussion-based learning that is in question. In the 
discussion-based learning, students process information by themselves while the teacher is prompting. This provokes discussions. And, of course, there are other methods as well, such as exploratory learning, but they all take their own time." [Eric]

He continued by saying that he prefers no single method over the rest, but "when they are applied in parallel or depending on the situation the aims [of teaching] can be reached." Eric's conception of instructional approaches is sophisticated and his conception of how they can be used flexible.

Mike referred to student teachers when discussing instructional approaches. He had noticed that student teachers often use a theoretical approach: they initiate their teaching by presenting a definition. He himself preferred the use of examples as a starting-point in teaching. He also acknowledged that students' pre-knowledge could be used as a basis in teaching, but he claimed that he himself does not use that particular kind of approach:

"The teacher could use an approach in which s/he extracts [pre-]knowledge from students. For instance, in science teaching advance organizers are used to discuss some concept that is already familiar to students. I don't use this kind of approach." [Mike]

This quote shows that even Mike knows some of the different instructional approaches - the traditional deductive and inductive approaches and a modern student-centered approach; in his own teaching he preferred the inductive approach even if it might be considered as an out-dated approach from the perspective of learning theories. It seems that he has found his personal style of teaching mathematics.

Laura stated that a teacher's knowledge of the structures of mathematics affects the choice of instructional approaches: "how you transform the structure, what kind of lesson you will prepare, how you can get students to understand it best". It seems that Laura is referring to the didactic analysis in which the teacher transforms content knowledge in a form that students can adopt easily and she presents it using methods that are best suited for a particular learning situation (Klafki, 2000).

\subsubsection{Computer-Based Tools and Resources in Mathematics}

Computer-based tools and resources in mathematics were the most polarizing themes for the mathematics teachers. Rita considers this knowledge important for teachers. She used to use computers frequently in her teaching before graphic calculators became general at upper secondary school. She argues:

"Graphic calculators have a lot of potential and they are in the classroom all the time. If you use computers you have to move to some other place [a computer classroom] or bring a computer trolley into the classroom. Graphic calculators are versatile. This is the modern use of informatics in mathematics teaching, I think." [Rita]

Jenny also defended the use of computers in mathematics teaching. She said that in her practice school mathematics teachers rarely used computer-based tools and resources in mathematics teaching, even if they were well suited to the teaching of statistics and diagrams, for instance.

Laura did not consider computer-based tools and resources important. She questioned them: "Of course we suggest that student teachers should use computers in mathematics teaching, but I take computers with a pinch of salt: is this really the right way to teach mathematics?" Despite this, she taught her students that calculators were a different matter, since they were "part and parcel of mathematics teaching". David admitted that computer-based tools and resources play a polarized role in mathematics teaching. On one hand, they can help a teacher to teach mathematics, but on the other hand there is a risk that students will not understand certain concepts properly. He illustrated this by reference to the use of the graphical calculator:

"Of course, graphical calculators are good, for instance, for drawing graphs, but there is a certain risk. I've noticed that if a student does not draw enough graphs by hand s/he will never learn to understand that the y-coordinate equates to the value of function!" [David]

\subsubsection{History of Mathematics}

The history of mathematics polarized teachers' conceptions. Rita, for instance, regarded the history of mathematics neutrally. She thought that mathematics teachers have to know "something about the history of mathematics". Laura did not value history at a personal level because she felt that her knowledge of the history of mathematics was vague and she doubted whether it appeared in her teaching at all.

Mike and Eric considered knowledge of the history of mathematics important for mathematics teachers. Mike stated that, according to the national curriculum, history should be included in mathematics teaching, but he wondered how it might be imported into the actual teaching: "I wonder how the history should be introduced into mathematics teaching. Of course, there are analogies: if it took thousands of years for mankind to invent the 
zero, how on earth can pupils instantly understand what the zero actually is?" Mike concluded that perhaps this kind of minor reference to the history could be the best way to use historical knowledge. Eric had a motivational view of the history of mathematics in teaching. He stated: "It is an aspect that enlivens a teaching group and arouses students' interest in mathematics. Instead of just presenting a theory, its background will also be presented." Eric thought that every mathematics lesson should contain some history and that it would be impossible to understand mathematics without its history: "It's like building a house without foundations."

\subsubsection{Mathematical Problem-Solving}

Mathematical problem-solving was valued by all of the teachers. For Eric, mathematical problem-solving is a very important part of mathematics teaching. In his teaching mathematical problems are very practical in nature and they help students to apply mathematics in everyday situations. Laura thought that mathematical problem-solving is essential for a teacher as "a part of a mathematics teacher's identity". Mike and Julie thought that problem-solving is an essential part of mathematics. Mike stated that "mathematics is problem-solving by definition: there is no need for puzzles". Julie stated that problem-solving goes through all the dimensions of mathematics and hence "it is always present in mathematics teaching." In addition, Jenny considers knowledge of mathematical problem-solving important for a mathematics teacher. She considered problem-solving to be a way of interesting students in mathematics.

\subsubsection{Visualizations and Hands-on Work in Mathematics}

All of the teachers considered knowledge of visualizations and hands-on work essential for a mathematics teacher. Julie considered that, for mathematics to be understood properly, hands-on work and visualizations are needed, but one has to remember the nature of mathematics: mathematics is not an empirical science. Laura also considered it important but stressed that it is difficult for a teacher as well:

"I feel that visualizations and hands-on work are somehow problematic. In lower secondary school there are also very weak students and, for instance, polynomials appear very abstract to them. It is a real challenge for the teacher to illustrate polynomials at the students' level to make the learning of them possible." [Laura]

Rita emphasized that visualizations are more used in mathematics teaching than hands-on work. David's view was rather similar. He thought that hands-on work and visualizations should form the first phase of a student's learning process: concepts can be introduced at a later stage.

In sum, most of the literature-based dimensions of teacher knowledge were highly respected by the mathematics teachers. Various different kinds of reasons for the importance of dimensions were, however, presented. For instance, reasons for the use of problem-solving could be either typical for mathematics as a science, and hence motivational, or it could be regarded as a way to help students to apply mathematics in everyday situations. In addition, computer-based tools and resources in mathematics and the history of mathematics were topics that divided the teachers' opinions.

\section{Discussion and Recommendations}

Mentor mathematics teachers who guide or supervise student teaching play a vital role in mathematics teacher education because they are expected to help student teachers to combine their study of mathematics with their study of educational theories so that they will learn to teach mathematics efficiently. To be capable of managing this demanding task, mentor teachers need to have a profound understanding of both of these theoretical frameworks per se. Among such important theoretical frameworks are the basic concepts of teacher knowledge and mathematical knowledge required for teaching mathematics.

The results of the first part of the interview indicated that the mentor teachers possessed rather organized views about the teacher knowledge required of a skilful mathematics teacher, but they described such teacher knowledge in their own words rather than in theoretical terms. All of the seven teachers started by emphasizing the importance of content knowledge in mathematics. For the most part, the teachers emphasized the teacher's ability to transform subject matter knowledge for teaching purposes. This is the fundamental idea of pedagogical content knowledge, PCK (see Shulman, 1986, 1987, 1999), but the mentor teachers did not use this term to describe this type of knowledge. The other knowledge type most frequently mentioned was knowledge of students in mathematics. This did not, however, refer to knowledge of students' preconceptions as an essential part of theory of teacher knowledge but to a general knowledge of students: what kind of learners they are individually and as teaching groups. Noteworthy here is the observation that these two knowledge domains were intertwined: in order to transform subject matter knowledge for teaching, one has to know the students.

The second part of the interview showed that, on one hand, the mentor teachers valued most of the types of 
mathematical knowledge required for teaching mathematics that are emphasized in the literature even if they did not discuss these knowledge types in the part of their interview. Furthermore, teachers' personal views of certain types differed from the actual scientific conceptions. One of these ambiguous knowledge types dealt with the structures of mathematical knowledge. While some teachers possessed a conception based on mathematics theory, others demonstrated only a student-oriented conception of the concept. According to this conception, a knowledge or understanding of the structure of mathematical knowledge means that teachers need to understand how students construct mathematical knowledge on the basis of their existing knowledge, rather than having a mathematical view of mathematical knowledge. This discrepancy can be understood on the basis of the results published by Moreira and David (2008). They discovered that the structures of university mathematics and school mathematics are not identical: for instance, some of the values and forms involved in conceptualizing objects may conflict with the demands of school practice. These findings challenge teacher education by making these conflicts explicit and raising them as topics for discussion with student teachers. Moreira and David (2008) suggest that this, in turn, may help student teachers to develop a professionally relevant conception of university-level mathematics. There is no doubt that mentor teachers occupy a vital position in this process in the Finnish context.

Another ambiguous knowledge type was mathematical problem-solving; the mentor teachers' view of this was generally not student-centered: a majority of the teachers saw it to be a natural and essential part of mathematics teaching per se. Only one teacher referred to students by saying that mathematical problem-solving can be used to motivate students. Our findings differ, therefore, from those obtained by Pehkonen (1993). In his study, mathematics teacher educators regarded problem-solving as of primary importance from the students' point of view in developing their mathematical thinking and creativity, but only of secondary importance from the mathematics point of view in terms of learning mathematics better. According to Pehkonen's results, teacher educators considered mathematical problem-solving important because it is a way of developing students' cognitive skills and because it helps students to master the mathematics being studied.

However, knowledge of the history of mathematics and computer-based tools and resources in mathematics were not considered by all the mentor teachers to be important for a mathematics teacher. Some teachers thought that the history of mathematics in some way occupied a neutral aspect in mathematics teaching: a teacher simply has to know something about the topic. Those teachers who regarded it as important for mathematics teachers explained that history could be used as an analogy in learning or as an aspect of mathematics that is really needed for a proper understanding of mathematics. Ernest (1993) has suggested that a teacher's view of mathematics may form the basis of a teacher's mental models in the teaching and learning of mathematics. We can only express our doubts about the way in which the notion of the importance of the history of mathematics in mathematics teaching is seen through the way in which these teachers teach mathematics.

Computer-based tools and resources in mathematics polarized the teachers' responses as well. Some of them thought that ICT in mathematics teaching is important and can help students to learn. Others were more skeptical and emphasized the importance of teacher guidance when ICT is applied in teaching. John (2005) has also reported a similar dualism amongst secondary mathematics teachers in the United Kingdom. According to his results, most of the teachers who participated in his study were comfortable with the deployment and use of ICT, but they also held some reservations about the possibility of a loss of basic mathematical skills and thinking processes.

The results showed that the mentor teachers conceptualized teacher knowledge in mathematics mostly in their own terms, rather than by using theoretical terms based on the literature. In addition, some theoretical terms seem to be ambiguous for the mentor teachers. These can cause difficulties in discussions between mentor teachers and student teachers and also between mentor teachers and other university teacher educators, and hence they may have a negative influence on student teaching in general. It has already been reported that if the teaching of mentor teachers differs from the educational theories that student teachers have recently learnt, the student teachers may experience difficulties in their student teaching (Black \& Halliwell, 2000; Meijer, Verloop, \& Beijaard, 1999). Lavonen et al. (2007, p. 58) have also claimed that connecting student teachers' studied in mathematics and in education is a major challenge for Finnish mathematics teacher education. Finnish mentor teachers undoubtedly occupy a key position in this process and have a good opportunity to respond to this challenge. Our results indicate, however, that teachers may lack the concepts needed to discuss teacher knowledge even if they are expert in demonstrating effective teaching. Thus we can see that there is a possibility that mentor teachers will be unable to support student teachers in their professional development as effectively as they should be able to. On the other hand, mentor teachers' different personal views about the importance of types of teacher knowledge, such as history of mathematics or computer-based tools and resources, may be 
valuable for student teachers when they are reflecting their own view of knowledge for teaching and the type of a teacher they want to become.

One of the important aims of student teaching is that student teachers should be provided with opportunities to observe, discuss, and practice good mathematics teaching. If mentor teachers do not update their knowledge, student teaching will be inadequately linked with theoretical studies of education, and student teachers may even think that theories are irrelevant. Our results suggest that the mentor teachers should be offered in-service education about teacher knowledge in mathematics. Although there are strong links between teacher's mathematical knowledge and quality of mathematics teaching, the relationship is complicated and mediated by several factors (see Hill, Blunk, Charalambous et al., 2008). The same is possibly true with the relationship of mentor teachers' views of teacher knowledge and their actual mathematics instruction and tutoring practice of student teachers which is an issue that deserves more attention in this field.

\section{References}

Anderson, D. (2006). The role of cooperating teachers' power in student teaching. Education, 128(2), 307-323.

Arcavi, A. (2003). The role of visual representations in the learning of mathematics. Educational Studies in Mathematics, 52(3), 215-241. http://dx.doi.org/10.1023/A:1024312321077

Asikainen, M. A., \& Hirvonen, P. E. (2010). Finnish cooperating physics teachers' conceptions of physics teachers' teacher knowledge. Journal of Science Teacher Education, 21, 431-450. http://dx.doi.org/10.1007/s10972-010-9187-y

Ball, D. L. (1988). Unlearning to teach mathematics. For the Learning of Mathematics, 8(1), 40-48.

Bandura, A. (1977). Self-efficacy: Toward a unifying theory of behavioural change. Psychological Review, 84(2), 191-215. http://dx.doi.org/10.1037/0033-295X.84.2.191

Black, A. L., \& Halliwell, G. (2000). Accessing practical knowledge: How? Why? Teaching and Teacher Education, 16, 103-115. http://dx.doi.org/10.1016/S0742-051X(99)00045-1

Borko, H., \& Mayfield, V. (1995). The roles of the cooperating teacher and university supervisor in learning to teach. Teaching and Teacher Education, 11(5), 501-518. http://dx.doi.org/10.1016/0742-051X(95)00008-8

Boz, N., \& Boz, Y. (2008). A qualitative case study of prospective chemistry teachers' knowledge about instructional strategies: Introducing particulate theory. Journal of Science Teacher Education, 19(2), 135-156. http://dx.doi.org/10.1007/s10972-007-9087-y

Brinkmann, A. (2001). Mathematical networks. Conceptual foundation and graphical presentation. In R. Soro (Ed.), Current State of Research on Mathematical Beliefs X. Proceedings of the MAVI-10 European Workshop (pp. 7-16). Turku: University of Turku.

Burke Johnson, R., Onwuegbuzie, A. J., \& Turner, L. A. (2007). Toward a definition of mixed methods research. Journal of Mixed Methods Research, 1(2), 112-133. http://dx.doi.org/10.1177/1558689806298224

Chapman, O. (2004). Facilitating peer interactions in learning mathematics: Teachers' practical knowledge. In M. J. Høines \& A. B. Fuglestad (Eds.), Proceedings of the PME28 Conference, 2 (pp. 191-198). Bergen: Bergen University College.

Chinnappan, M., \& Lawson, M. J. (2005). A framework for analysis of teachers' geometric content knowledge and geometric knowledge for teaching. Journal of Mathematics Teacher Education, 8, 197-221. http://dx.doi.org/10.1007/s10857-005-0852-6

Clement, D. H. (1999). "Concrete" manipulatives, concrete ideas. Contemporary Issues in Early Childhood, 1(1), 45-60. http://dx.doi.org/10.2304/ciec.2000.1.1.7

Cobb, P., \& Steffe, L. P. (2011). The constructivist researcher as teacher and model builder. In E. Kraffer, K. Gravemeijer, \& A. Sfard (Eds.), Mathematics Education Library: Vol. 48. A Journey in Mathematics Education Research (pp. 18-30). Netherlands: Springer. http://dx.doi.org/10.2307/749161

Cobb, P., Yackel, E., \& Wood, T. (1992). A constructivist alternative to the representational view of mind in mathematics education. Journal for Research in Mathematics Education, 23(1), 2-33.

Eisenhart, M., Borko, H., Underhill, R., Brown, C., Jones, D., \& Agard, P. (1993). Conceptual knowledge falls through the cracks: Complexities of learning to teach mathematics for understanding. Journal for Research in Mathematics Education, 24(1), 8-40. http://dx.doi.org/10.2307/749384

Ernest, P. (1993). The impact of beliefs on the teaching of mathematics. In P. Ernest (Ed.), Mathematics Teaching. 
The State of Art (pp. 249-254). New York: The Falmer Press.

Fauvel, J., \& van Maanen, J. (2000). History in Mathematics Education. The ICMI Study. Dortrecht: Kluwer.

Feiman-Nemser, S., \& Buchmann, M. (1986). The first year of teacher preparation: Transition to pedagogical thinking? Journal of Curriculum Studies, 18(3), 239-256. http://dx.doi.org/10.1080/0022027860180302

Haapasalo, L., \& Silfverberg, H. (2007). Technology enriched mathematics education. In E. Pehkonen, M. Ahtee, \& J. Lavonen (Eds.), How Finns Learn Mathematics and Science (pp. 165-182). Rotterdam/Taipei: Sense Publishers.

Hill, H. C., Blunk, M. I., Charalambous, Y. C., Lewis, J. M., Phelps, C. C., Sleep, L., \& Ball, D. L. (2008). Mathematical knowledge for teaching and the mathematical quality of instruction: An exploratory study. Cognition and Instruction, 26(4), 430-511. http://dx.doi.org/10.1080/07370000802177235

Hopmann, S., \& Riquerts, K. (2000). Starting a dialogue: A beginning conversation between Didaktik and the curriculum traditions. In I. Westbury, S. Hopmann, \& K. Riquarts (Eds.), Teaching as a Reflective Practice. The German Didaktik Tradition (pp. 3-12). Mahwah, NJ: Lawrence Erlbaum Associates.

Huberman, A. M., \& Miles, M. B. (1994). Data management and analysis methods. In N. K. Denzin \& Y. S. Lincoln (Eds.), Handbook of Qualitative Research (pp. 428-444). California: Sage Publications.

John, P. (2005). The sacred and the profane: Subject sub-culture, pedagogical practice and teachers' perceptions of the classroom uses of ICT. Educational Review, 57(4), 471-490. http://dx.doi.org/10.1080/00131910500279577

Klafki, W. (2000). Didaktik analysis as the core of the preparation of instruction. In I. Westbury, S. Hopmann, \& K. Riquarts (Eds.), Teaching as a reflective practice. The German Didaktik Tradition (pp. 139-160). London: Lawrence Erlbaum Associates.

Koerner, M., O'Connell Rust, F., \& Baumgardner, F. (2002). Exploring roles in student teaching placements. Teacher Education Quarterly, 35-58.

Kurki-Suonio, K., \& Kurki-Suonio, R. (1994). The Concept of Force in the Perceptional Approach. In H. Silfverberg \& K. Seinelä (Eds.), Ainedidaktiikan teorian ja käytännön kohtaaminen. Matematiikan ja luonnontieteiden opetuksen tutkimuspäivät 24.-25.09.93 (pp. 321-334). Reports from the Department of Teacher Education in Tampere, University of Tampere, A18/1994.

Kvale, S. (1996). InterViews - An Introduction to Qualitative Research Interviewing. Thousand Oaks: Sage Publications.

Lavonen, J., Krzywacki-Vainio, H., Aksela, M., Krokfors, L., Oikkonen, J., \& Saarikko, H. (2007). Pre-service teacher education in chemistry, mathematics, and physics. In E. Pehkonen, M. Ahtee, \& J. Lavonen (Eds.), How Finns Learn Mathematics and Science (pp. 49-68). Rotterdam/Taipei: Sense Publishers.

Lawson, M. J., \& Chinnappan, M. (1994). Generative activity during geometry problem solving: Comparison of the performance of high-achieving and low achieving students. Cognition and Instruction, 12, 61-93. http://dx.doi.org/10.1207/s1532690xci1201_3

Lerman, S. (1983). Problem-solving or knowledge centred: The influence of philosophy on mathematics teaching. International Journal of Mathematical Education in Science and Technology, 14(1), 59-66. http://dx.doi.org/10.1080/0020739830140109

Ma, X., \& Xu, J. (2004). Determining the causal ordering between attitude toward mathematics and achievement in mathematics. American Journal of Education, 11(3), 256-280. http://dx.doi.org/10.1086/383074

Meijer, P. C., Verloop, N., \& Beijaard, D. (1999). Exploring language teachers' practical knowledge about teaching reading comprehension. Teaching and Teacher Education, 15, 59-54. http://dx.doi.org/10.1016/S0742-051X(98)00045-6

Moreira, P. C., \& David, M. N. (2008). Academic mathematics and mathematical knowledge needed in school teaching practice: Some conflicting elements. Journal of Mathematics Teacher Education, 11, 23-40. http://dx.doi.org/10.1007/s10857-007-9057-5

Pajares, M. F. (1992). Teachers' beliefs and educational research: Cleaning up a messy construct. Review of Educational Research, 62(3), 307-332. http://dx.doi.org/10.3102/00346543062003307

Pehkonen, E. (1993). What are Finnish teacher educators' conceptions about the teaching of problem solving in mathematics? European Journal for Teacher Education, 16(3), 237-256. 
http://dx.doi.org/10.1080/0261976930160306

Potari, D., \& Jaworski, B. (2002). Tackling the complexity of mathematics teaching: Using the Teaching Triad as a Tool for Reflection and Analysis. Journal of Mathematics Teacher Education, 5(4), 349-378. http://dx.doi.org/10.1023/A:1021214604230

Reynolds, D., Treharne, D., \& Tripp, H. (2003). ICT - the hopes and the reality. British Journal of Educational Technology, 34(2), 151-167. http://dx.doi.org/10.1111/1467-8535.00317

Rhoads, K., Radu, I., \& Weber, K. (2011). The teacher internship experiences of prospective high school mathematics teachers. International Journal of Science and Mathematics Education, 9, 999-1022. http://dx.doi.org/10.1007/s10763-010-9267-7

Schoenfeld, A. H. (1992). Learning to think mathematically: Problem solving, metacognition, and sense making in mathematics. In G. A. Douglas (Ed.), Handbook of Research on Mathematics Teaching and Learning (pp. 334-370). New York: Macmillan.

Shulman, L. (1986). Those who understand: Knowledge growth in teaching. Educational Researcher, 15(2), 4-14.

Shulman, L. (1987). Knowledge and teaching: Foundations of the new reform. Harvard Educational Review, $57(1), 1-22$.

Shulman, L. S. (1999). Knowledge and teaching: Foundations of the new reform. In J. Leach \& R. E. Moon (Eds.), Learners \& Pedagogy (pp. 61-77). London: Paul Chapman Publishing in association with The Open University.

Steele, M. (2005). Comparing knowledge bases and reasoning structures in discussions of mathematics and pedagogy. Journal of Mathematics Teacher Education, 8, 291-328. http://dx.doi.org/10.1007/s10857-005-0854-4

Stylianides, A. J., \& Ball, D. L. (2008). Understanding and describing mathematical knowledge for teaching: Knowledge about proof for engaging students in the activity of proofing. Journal of Mathematics Teacher Education, 11(4), 307-332. http://dx.doi.org/10.1007/s10857-008-9077-9

Vosniadou, S., \& Verschaffel, L. (2004). Extending the conceptual change approach to mathematics learning and teaching. Special Issue of Learning and Instruction, 14(5), 445-451. $\mathrm{http}: / / \mathrm{dx}$. doi.org/10.1016/j.learninstruc.2004.06.014

Wengraf, T. (2001). Qualitative Research Interviewing: Semi-Structured, Biographical and Narrative Methods. London: Sage.

Zan, R., Brown, L., Evans, J., \& Hannula, M. S. (2006). Affect in mathematics education. An introduction. Educational Studies in Mathematics, 63, 113-121. http://dx.doi.org/10.1007/s10649-006-9028-2

\section{Notes}

Note 1. Knowledge of the structure of mathematics is sometimes termed conceptual knowledge (Eisenhart et al., 1993).

Note 2. Some example interview questions: Could you describe a skillful mathematics teacher? What kind of knowledge should a skillful mathematics teacher possess? What kind of sub-types do these knowledge types consist of?

Note 3. We formulated the themes in the way that would be understandable for mentor teachers even if they were not very familiar with the terms used in the theory of teacher knowledge based on the work of Lee Shulman. For this reason we did not use terms such as subject matter knowledge or pedagogical content knowledge. 